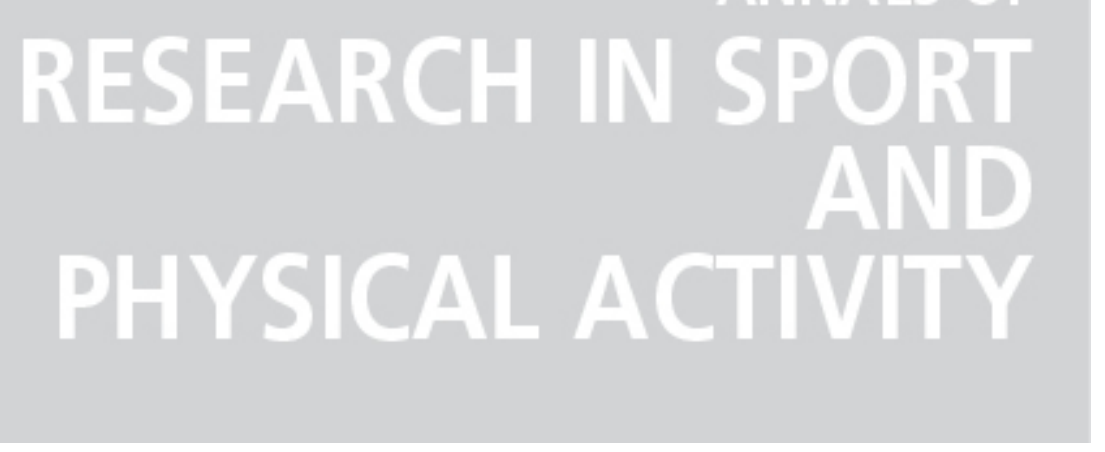

\title{
Estimated physical activity and inactivity in urban mexican school youth
} $\begin{array}{ll}\text { Autor(es): } & \text { Siegel, Shannon R.; Malina, Robert M.; Peña Reyes, Maria Eugenia; } \\ \text { Cárdenas Barahona, Eyra E. }\end{array}$

Publicado por: Imprensa da Universidade de Coimbra

URL persistente:

URI:http://hdl.handle.net/10316.2/3361

DOI:

DOI:http://dx.doi.org/10.14195/2182-7087_1_2

Accessed : $\quad$ 26-Apr-2023 16:12:15

A navegação consulta e descarregamento dos títulos inseridos nas Bibliotecas Digitais UC Digitalis, UC Pombalina e UC Impactum, pressupõem a aceitação plena e sem reservas dos Termos e Condições de Uso destas Bibliotecas Digitais, disponíveis em https://digitalis.uc.pt/pt-pt/termos.

Conforme exposto nos referidos Termos e Condições de Uso, o descarregamento de títulos de acesso restrito requer uma licença válida de autorização devendo o utilizador aceder ao(s) documento(s) a partir de um endereço de IP da instituição detentora da supramencionada licença.

Ao utilizador é apenas permitido o descarregamento para uso pessoal, pelo que o emprego do(s) título(s) descarregado(s) para outro fim, designadamente comercial, carece de autorização do respetivo autor ou editor da obra.

Na medida em que todas as obras da UC Digitalis se encontram protegidas pelo Código do Direito de Autor e Direitos Conexos e demais legislação aplicável, toda a cópia, parcial ou total, deste documento, nos casos em que é legalmente admitida, deverá conter ou fazer-se acompanhar por este aviso. 
(1) 2011

\section{ANNALS OF RESEARCH IN SPORT PHYSICAL ACTIVITY

FACULDADE DE

CIÊNCIAS DO DESPORTO E EDUCAÇÃO FÍSICA DA UNIVERSIDADE DE COIMBRA IMPRENSA DA UNIVERISDADE DE COIMBRA 
2・PHYSICAL ACTIVITY

ESTIMATED PHYSICAL ACTIVITY AND INACTIVITY IN URBAN MEXICAN SCHOOL YOUTH 
Shannon R. Siegel ${ }^{1}$, Robert M. Malina², Maria Eugenia Peña Reyes ${ }^{3}$,

Eyra E. Cárdenas Barahona ${ }^{4}$

\section{ABSTRACT}

The purpose of this study is to compare estimates of physical activity and physical inactivity in urban Mexican school youth.

A cross-sectional survey was conducted with 1085 school youth (525 males, 560 females), 9-18 years of age resident in Mexico City. Socioeconomic status (SES) was estimated. The Physical Activity Questionnaire (PAQ) was used to estimate activity over the past week. Television and video game time were noted. Height and weight were measured; the BMI was calculated. Youth were classified as normal weight, overweight or obese using international criteria. MANOVA was used to compare physical activity and inactivity by SES, age group (9-10, 11-13, and 14-18 years) within and between sexes, and by weight status.

The most common non-sport physical activities are walking and jogging in girls and jogging, walking and bicycling in boys. Frequent ( $\geq 3$ times per week) participation in sport activities is more common among boys than girls. Within each age group and sex, PAQ scores and screen time do not differ by SES, and boys are more physically active than girls. Boys spend more time playing video games than girls at all ages. Younger males and females have higher activity scores than the oldest group. Correlations between the $\mathrm{BMI}$ and the PAQ score are low. Estimated physical activity and screen time do not differ among youth by weight status.

The majority of urban Mexican youth in this sample had insufficient physical activity and seemingly too much inactivity, both of which have negative implications on health status.

KEYWORDS: Youth, Physical activity, BMI, Mexico City.

\footnotetext{
${ }^{1}$ Department of Kinesiology, California State University - San Bernardino, 5500 University Parkway, San Bernardino, CA, ssiegel@csusb.edu.

2 Professor Emeritus, Department of Kinesiology and Health Education, University of Texas at Austin, and Research Professor, Tarleton State University, Stephenville, TX, 10735 FM 2668, Bay City, TX 77414, rmalina@ skyconnect.net.

${ }^{3}$ Escuela Nacional de Antropología e Historia, Instituto Nacional de Antropologia e Historia, Periferico Sur y Zapote s/n, Col. Isidro Fabela, CP 14030 Delegacion Tlalpan, Mexico, DF, eugeniapere@ prodigy.net.mx.

${ }^{4}$ Address for correspondence:Shannon R. Siegel, Department of Kinesiology, California State University, San Bernardino, 5500 University Parkway, San Bernardino, CA, Phone: 909537 5358, ssiegel@csusb.edu.
} 


\section{INTRODUCTION}

Regular physical activity is associated with several health, physical fitness and behavioral benefits in youth, including bone mineral, adiposity, components of cardiovascular health and metabolic syndrome, aerobic fitness, muscular strength and endurance, self-concept, anxiety and depression symptoms, and academic performance (Malina, 1990; Strong et al., 2005; Physical Activity Guidelines Committee [PAGC], 2008). Given the benefits associated with physical activity, there is considerable interest internationally in the assessment of physical activity and inactivity among youth. Examples are the 2001/2002 Health Behaviour in School Aged Children Survey (Currie et al., 2004) and the Global School-Based Student Health Survey (Centers for Disease Control [CDC], 2005). The former includes an estimate of the percentages of 13 year old youth from 31 European countries and the United States and Canada who attained recommended levels of physical activity, defined as at least 1 hour of moderate intensity activity on five or more days of the week, while the latter reports the percentage of youth 13-15 years who were physically active for 7 days per week and who spent 3 or more hours in sedentary activities on a typical day.

Information on the physical activity of Mexican youth is limited and methods of assessment and reporting vary. Boys and girls, 9-16 years of age in Mexico City spent, on average, 2.1 and 1.6 hours per day of moderate-to-vigorous activity, respectively, and 4.3 and 3.8 hours per day of "total video viewing,", respectively (Hernández et al., 1999; Hernández et al., 2000). Adolescents and young adults 11-24 years of age in Morelos spent, on average, 0.5 hour per day in vigorous activity and 3.7 hours per day viewing television (LazcanoPonce et al., 2003). About $82 \%$ and $51 \%$ of ninth grade boys and girls in Matamoros, respectively, reported participation in moderate or vigorous physical activity and about 95\% of youth of both sexes were enrolled in physical education (Perez, Reininger, Aguirre Flores, Sanderson, \& Roberts, 2004). In the 2006 National Health and Nutrition Survey, 24\% and $35 \%$ of adolescents $10-19$ years of age were classified as moderately active and active, respectively, and about $50 \%$ viewed television $>2$ hours per day (Hernández, Villabos, \& Rauda, 2006).

The purpose of this study is to compare estimates of physical activity and physical inactivity in urban Mexican youth 9-18 years by age group, sex and weight status. Mexico City is very densely populated, sits at $2200 \mathrm{~m}$ altitude and has more or less chronic problems with air pollution, all of which are factors which may influence physical activity. For example, during pollution alerts, outdoor activities at schools are suspended for the duration of the alert. Low levels of habitual physical activity have been implicated as risk factors for obesity in Mexico City youth (Hernández et al., 1999). The prevalence of obesity in Mexican youth has increased significantly between the 1999 and 2006 national nutritional surveys, more so among youth 5-11 than 12-19 years (Rivera Dommarco et al., 2006). Given the potential 
health benefits of physical activity in youth (Malina, 1990; Strong et al., 2005; PAGC, 2008), study of physical activity and inactivity and weight status of Mexican youth has potential implications for public health.

\section{MATERIAL AND METHODS}

A cross-sectional survey of youth resident in Mexico City was conducted in the Spring of 1998 after the Easter break. The project was approved by the University Committee for Research Involving Human Subjects of Michigan State University and was sponsored by the Escuela Nacional de Antropología e Historia (ENAH). The project was approved by authorities of the schools involved and each participant provided informed consent.

The sample included 1085 school youth, 525 males and 560 females, 9 through 18 years of age. All youth were enrolled in primary (primaria), secondary (secundaria) and high school (preparatoria) schools in the Federal District at the time of the survey. Social class or socioeconomic status (SES) was estimated primarily on the basis of school location. Home location (delegación and colonía) and occupation of parents as reported by the students, if necessary, were used to corrobate SES designation based on school location. With the assistance of school authorities and colleagues at ENAH, this information was used to classify the SES of each participant as low, middle and high. A similar protocol was used in another survey of physical activity of Mexico City youth, i.e., classification of SES on the basis of school attended (Hernández et al., 1999). Allowing for limitations of method of designation, the distribution of subjects by SES was: low, $41.2 \%$; medium, $32.5 \%$; and high, $26.3 \%$.

The Physical Activity Questionnaire (PAQ) developed for Canadian youth was used. The PAQ has two forms, one for older children (Kowalski, Crocker, \& Faulkner, 1997) and another for adolescents (Kowalski, Crocker, \& Kowalski, 1997). The former is designed for children from fourth to eighth grades and the latter for youth from eighth to twelfth grades. The only difference between PAQ forms is an item about activity during recess for children. Regularity of recess varied among schools and between primary and secondary schools, though free time after lunch was available. Given the age range of the sample and inconsistency of recess periods in both primary and secondary schools, the PAQ form for adolescents was used.

The PAQ required the student to recall activities over the past seven days, which was consistent with evidence suggests that a record of seven days provided a reliable estimate of the usual pattern of physical activity in youth (Trost, Pate, Freedson, Sallis, \& Taylor, 2000). In the PAQ, physical activities were described as sports, games or dances that make the individual breathe hard, make the legs feel tired, or make the individual sweat (Crocker, Bailey, 
Faulkner, Kowalski, \& McGrath, 1997). Specific questions included the following: frequency of participation in sport and non-sport physical activities during free time; participation in physical education; activities at lunch time (in addition to eating); activities immediately after school, during evenings, and on weekends; and an overall estimate of physical activity during free time. Items were answered on a five point scale. The average of the scores on each item provided an estimate of overall physical activity (PAQ score) which ranged from 1 (low) to 5 (high). A PAQ score $<3.0$ was approximately equivalent to 1.5-3 METS, a score 3.0-3.99 indicated about 3-5 METS (moderate activity) and a score $>4.0+$ indicated about $\geq 6$ METS. In the most recent compendium, moderate activities generally ranged from 3.5 to 6 METS, while vigorous activities > 6.0 METS (Ainsworth et al., 2000).

Several items in the PAQ are not used to derive the physical activity score, but provide information on time spent viewing television and playing video games and perceived physical condition and perceived activity level compared to age and sex peers. Television and video game time was analyzed separately as an indicator of physical inactivity. Responses on perceived physical activity and fitness compared to peers provided an estimate of convergent validity of the PAQ (Kowalski, Crocker, \& Faulkner, 1997; Kowalski, Crocker, \& Kowalski, 1997). Perceived physical activity included five options compared to peers of the same age and sex: very inactive, less active, just as active, a little more active, or much more active. Perceived fitness (physical condition) included four options compared to peers of the same age and sex: very fit, fitter than most, less fit than most and very unfit.

The PAQ was translated into Spanish and field tested in a pilot survey of approximately 100 children 9-12 years of age from three schools in middle to high SES neighborhoods. Changes were made as needed without altering the essence of the PAQ.This was necessary for the question on perceived physical fitness which had four choices in the English version of the PAQ. The Spanish translation did not give clear enough delineation among the four choices for perceived fitness. The choices were thus reduced to three: very fit (excelente), less fit (menor que la de los demás), or worse (peor que la de los demás) compared to age and sex peers. The Spanish translation of the PAQ was subsequently finalized and administered to the survey sample in the classroom setting. Specific procedures were explained by a member of the research team to the students. The research assistant remained in the classroom while the students completed the PAQ; he/she also answered questions as necessary. A research assistant checked each questionnaire for completeness, and missing or incomplete information was requested. The PAQ was completed by 1085 students, who were subsequently classified into three age groups: $9-10$ years (boys $10.3 \pm 0.4$, girls $10.3 \pm 0.5$ ), $11-13$ years (boys $11.9 \pm 0.6$, girls $11.8 \pm 0.6)$ and $14-18$ years $(16.5 \pm 0.7$, girls $16.5 \pm 0.6)$ to approximate, in general, late childhood, the transition into adolescence adolescence, and later adolescence, respectively. 
Cronbach's alpha for the PAQ $(\alpha=0.72)$ indicated acceptable internal consistency. Testretest correlations for the PAQ were 0.75 and 0.82 in Canadian boys and girls, respectively (Kowalski, Crocker, \& Faulkner, 1997). The PAQ was moderately correlated with several indicators of physical activity in Canadian youth 13-20 years (Kowalski, Crocker, \& Kowalski, 1997). On the other hand, correlations between the PAQ (Crocker, Holowachuk, \& Kowalski, 2001) and another 7-day physical activity recall instrument (Sallis et al., 1985) and estimates of activity with Tritrac and Caltrac monitors were low, leading the authors to question the viability of mechanical recorders for assessing physical activity over extended periods (Crocker et al., 2001). Correlations between the PAQ and accelerometry were somewhat higher in rural, urban and Old Order Mennonite Canadian youth 9-12 years (Tremblay, Barnes, Copeland, \& Esliger, 2003), while correlations between the PAQ and overall physical activity and moderate-to-vigorous activity measured with an Actigraph monitor in youth were moderate (Jantz, Lutuchy, Wenthe, \& Levy, 2008). The PAQ was also relatively stable across a two year interval between 11 and 13 years of age (Jantz et al., 2008).

Height and weight of each participant were measured; the BMI was calculated. Children were classified as thin, normal weight, overweight or obese using international criteria (Cole, Bellizzi, Flegal, \& Dietz, 2000; Cole, Flegal, Nicholls, \& Jackson, 2007). The criteria for thinness approximated two standard deviations below age- and sex-specific reference means and the WHO criterion for grade 2 thinness in adults $\left(B M l<17.0 \mathrm{~kg} / \mathrm{m}^{2}\right)$. The term thinness was used as the terms wasting and underweight are often confusing (Cole et al., 2007). Only 6 boys and 3 girls were classified as thin (low BMI for age). Five of the 6 boys were 11-13 years; one was 16 years. The 3 girls were 9-11 years and pre-menarcheal. Given the ages, it is possible that the thinness of the subjects could reflect late timing of the adolescent growth spurt (Malina, Bouchard, \& Bar-Or, 2004). Given the small number, they were included with normal weight children for the analyses.

The frequencies of participation in non-sport and sport physical activities were summarized to provide an overview of specific activities reported by urban Mexican youth. Descriptive statistics for PAQ scores, television time, video game time, and total screen time (combined television and video game) were calculated by age group and sex and by SES within each group. MANOVA was used to test differences in physical activity and indicators of inactivity among SES groups within age sex groups, between sexes within each age group (9-10, 11-13, and 14-18 years) and between age groups within sex. MANCOVA, with age as the covariate, was used to evaluate PAQ scores by categories of perceived physical activity and fitness compared to peers as an estimate of convergent validity of the PAQ. Chi square was used to compare distributions of subjects by weight status. Differences in physical activity and inactivity of normal, overweight and obese youth within age group by sex were also tested with MANOVA. Bonferroni adjustments for multiple comparisons were used. An adjusted significance level of $p<0.05$ was accepted. 


\section{RESULTS}

The relative frequency of participation in non-sport and sport physical activities during the past week is summarized in Table 1. Using $\geq 3$ times per week as an index of frequent participation, walking and jogging are the most common non-sport physical activities in girls, followed by rollerblading/skating. Percentages of girls who report frequent participation in these three activities are lowest among older adolescent girls 14-18 years. Among boys, jogging is the most common non-sport physical activity with frequent participation, followed by reasonably similar percentages for walking and bicycling. Small percentages of youth of both sexes report participation in aerobics, dancing, weight lifting and skateboarding.

The majority of girls in the three age groups report no participation in sport activities except for volleyball and basketball among girls 9-10 and 11-13 years. Relatively few older adolescent girls 14-18 years report frequent ( $\geq 3$ times per week) participation in sport activities. Among boys, soccer is the most common sport with frequent participation; $73 \%$ of 9-10 year old and $84 \%$ of $11-13$ year old compared to $51 \%$ of $14-18$ year old boys report frequent participation in soccer. Frequent participation in basketball, volleyball and American football occurs more often by 9-10 year old boys, but frequent participation in basketball occurs more often among older adolescent boys 14-18 years. Frequent participation in baseball and swimming is similar in 9-10 and 11-13 year old boys and is lower among older adolescent boys. Small percentages of boys and girls report participation in martial arts and badminton, and several boys and girls reported participation in squash and gymnastics, respectively (not shown in the table).

Within each age group and sex, PAQ scores and the three indicators of screen time do not differ by SES (Table 2), and boys are more physically active than girls (Table 3). Television viewing time does not differ between boys and girls 9-10 and 11-13 years, but is significantly longer in boys 14-18 years. On the other hand, time spent playing video games and overall screen time is significantly greater in boys than girls in all age groups.

Comparisons of physical activity and screen time among age groups of boys and girls are summarized in Table 4. Boys and girls 9-10 and 11-13 years do not differ in PAQ scores, but both groups have higher PAQ scores than 14-18 year old boys and girls. Television viewing time does not differ by age among boys, but is greater among girls 9-10 and 11-13 years compared to girls $14-18$ years. Boys $9-10$ and 11-13 years do not differ in video game time and overall screen time, but both groups spent significantly more time in these activities than boys 14-18 years. Time spent in video games is significantly greater in 9-10 year old girls compared to girls 11-13 and 14-18 years. Overall screen time does not differ between girls 9-10 and $11-13$ years, but is significantly greater than among girls 14-18 years. 
PAQ scores by perceived category of physical activity and fitness differ significantly in both sexes (Table 5). Age-adjusted mean PAQ scores increase from youth of both sexes who perceived themselves as very inactive and less active to those who perceive themselves in the much more active categories. Boys and girls who perceive themselves as very fit compared to peers have significantly higher PAQ scores than those who perceive their fitness as less or worse than peers; youth in the latter two categories do not differ in PAQ.

Distributions of normal weight, overweight and obesity do not differ by SES in boys $\left(x_{2}=4.84, p=0.30\right)$ and girls $\left(x_{2}=7.36, p=0.12\right)$. Correlations between the PAQ and indicators of screen time and BMI are low (Table 6). BMI and PAQ are related only among boys 11-13 years (-0.19). BMI and television time are negatively related in boys $14-18$ years $(-0.15)$, but are positively and significantly correlated in girls 9-10 years $(0.14), 11-13$ years $(0.17)$ and the total sample (0.14). PAQ scores and indicators of screen time are compared among normal weight, overweight and obese youth in Table 7. Comparisons are consistent with the correlations. Only one comparison is significant among boys, but two others are of marginal significance, one in boys and one in girls. Among boys 11-13 yrs, the PAQ score declines significantly from normal weight to overweight to obesity. Among boys 14-18 years, video viewing and video games is higher in obese compared normal and overweight boys $(p=0.06)$; small samples of overweight and obese boys and risk of Type II error should be noted. The same

applies to television viewing time in girls 11-13 years. Overweight and obese girls spend more time viewing television compared to normal weight girls $(p=0.08)$.

\section{DISCUSSION}

Urban Mexican boys were more active than girls in each of the age groups, and within each sex, youth 9-10 and 11-13 years of age were more active than older adolescents 14-18 years of age. The decline in physical activity during adolescence in Mexican youth was consistent with the general trend for age-associated decline in activity from early through late adolescence (Malina et al., 2004; Boracino et al., 2009).

Comparative data based on the PAQ are summarized in Table 8. Standard deviations were similar for all samples. Mean PAQ scores for Mexican boys 9-10 and 11-13 years were reasonably consistent with those for Canadian boys in of the same age range (with one exception, boys 9-15 years), while mean PAQ scores of Mexican girls 9-10 and 11-13 years were lower than those for Canadian girls of the same age. On the other hand, PAQ scores of Mexican boys and girls 14-18 years were similar to those of urban Brazilian boys and girls 14-15 years and Canadian boys and girls 13-20 years. Mean PAQ scores for all late adolescent samples were lower than those of younger children. The results for Mexican and Canadian youth were 
consistent in indicating a decline in physical activity, on average, from late childhood and early adolescence into late adolescence.

PAQ scores cannot be converted into hours per week. Hence, direct comparison with the limited data for urban Mexican youth was not possible. In a survey of youth 9-16 years of age in Mexico City in 1997, boys and girls reported, on average, 2.1 and 1.6 hrs per day of moderate-to-vigorous physical activity (MVPA), respectively (Hernández et al., 1999). Using the same protocol, the average time spent daily in vigorous physical activity was $0.7 \mathrm{hr}$ and $0.4 \mathrm{hr}$ in adolescent and young adult males and females, respectively (Lazcano-Ponce, 2003). About $60 \%$ of adolescents $11-20$ years of age in the 2006 National Health and Nutrition Survey were classified as moderately active (4-6 hrs per week MVPA, 24\%) and active ( $\geq 7$ hrs per week MVPA, 35\%); the remainder was classified inactive ( $<4$ hrs per week MVPA, $40 \%$ ). Unfortunately, the national data were not partitioned by sex and age-related variation was not considered (Hernández et al., 2006).

It has been suggested that the PAQ assesses the level of moderate-to-vigorous physical activity over the preceding seven days (Kowalski, Crocker, \& Faulkner, 1997; Kowalski, Crocker, \& Kowalski, 1997). About one-half of urban Mexican boys 9-10 (45\%) and 11-13 $(50 \%)$ years had a PAQ score $\geq 3.0$, which suggested an adequate level of physical activity over the preceding seven days (Table 4). Only about $30 \%$ of older adolescent boys 14-18 years $(31 \%)$ and girls $9-10(27 \%)$ and $11-13(26 \%)$ years had PAQ scores $\geq 3.0$, while even fewer older adolescent girls $14-18$ years (14\%) had PAQ scores $\geq 3.0$. The majority of older urban Mexican youth of both sexes thus had relatively little moderate-to-vigorous physical activity in the past week. The proportion of youth with PAQ scores $\geq 4.0$, indicative of vigorous physical activity, was negligible, $6 \%$ in boys $9-10$ and $11-13$ years and $2 \%$ in boys $14-18$ years and $<1 \%$ among girls $9-18$ years.

Comparative data on activity levels of Latin American youth are limited. Mean PAQ scores of Brazilian youth 14-15 years are similar to urban Mexican youth 14-18 years (Table 8). Relatively small numbers of youth 13-15 years in Chile (boys, 15\%; girls, 7\%), Venezuela (boys, $12 \%$; girls, 5\%) and Guyana (boys, 17\%; girls, 15\%) reported that they were physically active for a total of at least one hour per day for 7 days (CDC, 2005). Among European and North American youth, about 30\% to $60 \%$ in boys and about $15 \%$ to $45 \%$ in girls 13 years of age from 31 European countries and the United States and Canada reported participation in at least 1 hour of moderate intensity activity on five or more days of the week (Currie et al., 2004). In the Youth Risk Behavior Survey in the United States, about two-thirds of high school youth reported participation in physical activities that made them "sweat and breathe hard" for 20 minutes or more on three of the past seven days (Youth Risk Behavior Survey [YRBS], 2004). 
Age-adjusted mean PAQ scores showed good concordance with categories of perceived physical activity and fitness compared to peers in both sexes (Table 5). The trend was stronger for perceived activity than perceived fitness. The results provided a reasonable estimate of convergent validity of the PAQ in Mexican youth. Partial correlations between the PAQ and perceived physical activity, controlling for age, were $0.25(p<0.001)$ in boys and 0.38 $(p<0.001)$ in girls. The corresponding correlation between the PAQ and perceived fitness, controlling for age, was similar in boys, 0.24 ( $p<0.001)$, but was lower in girls, $0.13(p<0.01)$.

Test-retest correlations for the PAQ were moderately high, 0.75 and 0.82 in Canadian boys and girls, respectively (Kowalski, Crocker, \& Faulkner, 1997), while correlations between the PAQ and several indicators of physical activity were moderate among Canadian youth 1320 years, 0.59 (Seven-Day Physical Activity Recall Interview, Sallis et al., 1985), 0.57 (Leisure Time Activity Questionnaire, Godin \& Shephard, 1985), and 0.33 (caltrac, Kowalski, Crocker, \& Kowalski, 1997). Correlations between the PAQ and estimates of activity with Tritrac and Caltrac monitors, on the other hand, were low, 0.07 to 0.16 (Crocker et al., 2001). Correlations between another 7-day physical activity recall instrument (Sallis et al., 1985) and Tritrac and Caltrac estimates of activity were also low, leading the authors to question the viability of mechanical recorders for assessing physical activity over extended periods (Crocker et al., 2001). Correlations between the PAQ and accelerometry were, respectively, $0.40,0.28$ and -0.02 in rural, urban and Old Order Mennonite Canadian youth 9-12 years (Tremblay et al., 2003). More recently, the PAQ was moderately correlated overall physical activity (rho = 0.47 ) and moderate-to-vigorous activity (rho $=0.49$ ) measured with an Actigraph monitor in an independent sample of youth, and was also relatively stable across a two year interval between 11 and 13 years of age (Jantz et al., 2008). In contrast of physical activity, the PAQ score was related to cardiorespiratory fitness in Hispanic and European American but not in African American children (step test, Moore et al., 2007), and in Canadian (step test, Kowalski, Crocker, \& Faulkner, 1997) and Brazilian (12 minute run, Rosendo da Silva \& Malina, 2000) adolescents.

Physical education is an important context for activity in the school setting and is compulsory in primary and secondary schools in Mexico. It was no surprise therefore that $94 \%-98 \%$ of boys and girls 9-13 years reported having physical education in the seven days preceding the survey. Among adolescents $14-18$ yrs, $75 \%$ of boys and $72 \%$ of girls reported having physical education. The fact that about one-fourth of older adolescents, $25 \%$ of boys and $28 \%$ of girls, did not have physical education in the preceding seven days may contribute to the adolescent decline in the PAQ. The percentage of adolescents having physical education was lower than estimates for ninth grade youth in Matamoros among whom about 95\% were enrolled in physical education (Perez et al., 2004). These estimates markedly contrasted those for United States high school students, among whom only about 50\% were enrolled in physical education class on one or more days in an average week in surveys conducted be- 
tween 1991 and 2003 (YRBS, 2004). Nevertheless, the important role of physical education as a medium for physical activity in Mexican youth is consistent with a systematic review of physical activity interventions in Latin America (Hoehner et al., 2008). Strength of evidence upon which to base an activity recommendation in Latin America was sufficient only for school physical education.

Only a small percentage of the urban Mexican youth reported no television viewing $(\sim 3 \%)$, but boys and girls spent, on average, 3.1 \pm 2.4 and $2.9 \pm 2.2 \mathrm{hrs}$ per day viewing television, respectively. The estimates were slightly higher than those reported for Mexico City youth $9-16$ years of age, $2.3 \pm 1.4$ and $2.4 \pm 1.6 \mathrm{hrs}$ per day in boys and girls, respectively (Hernandez et al., 1999), but lower than Morelos adolescents and young adults 11-24 years of age, 4.0 and 3.5 hrs per day in males and females, respectively (Lazcano-Ponce et al., 2003). About $57 \%$ and $58 \%$ of ninth grade boys and girls, respectively, in Matamoros reported watching, on average, $\geq 3$ hrs of television per day (Perez et al., 2004). In a national sample of Mexican adolescents 10-19 years, > 50\% spent more than 2 hrs per day and of these about $25 \%$ spent about 3 hrs per day in front of a television (Hernández et al., 2006). Allowing for variation in method of reporting and error of recall, the data for Mexican youth from different parts of the country were generally consistent and showed no sex difference in this form of physical inactivity.

In contrast, larger percentages of Mexico City youth reported not playing video games ( $21 \%-36 \%$ of boys, $48 \%-59 \%$ of girls). It was not known whether this reflected choice or accessibility. Of those who reported playing video games, boys spent significantly more time doing so than girls, $2.5 \pm 2.2$ and $1.8 \pm 1.7$ hours per day, respectively. These estimates were also higher than reported by an independent sample of Mexico City youth 9-16 years of age, $1.0 \pm 1.2$ hours per day by boys and $0.5 \pm 0.6$ hours per day by girls (Hernández et al., 1999).

34 The difference in video game time may reflect social class differences between samples. The present study included low, middle and high SES youth while the comparative study was limited to schools in low and middle income neighborhoods (Hernández et al., 1999). However, the three indicators of screen time did not differ by SES in the present sample of Mexican youth (Table 2).

Physical activity and time viewing television were not strongly related to weight status (Tables 5 and 6) and were not related with each other in this sample of urban Mexican youth. Correlations of the same magnitude were observed between the PAQ and BMI in European American children $(r=-0.16)$, and between the PAQ and \% Fat $(r=-0.10)$ in Hispanic American children; however, the PAQ and BMI were not correlated in African American and Hispanic American children (Moore et al., 2007). Among urban Brazilian youth 14-15 years, television time was related to overweight/obesity but the PAQ score was not (Rosendo da Silva \& Malina, 2003). Brazilian boys and girls reported watching television $>4$ hours per day compared to about 3 hours per day in the present study. Nevertheless, the results were consistent with a 
comprehensive meta-analysis which demonstrated a small but negative relationship between television viewing and physical activity (39 samples) and a negligible relationship between physical activity and fatness (52 samples); less extensive data for video/computer game use indicated similar low relationships with physical activity and fatness (Bandini, Schoeller, \& Dietz, 1990). The literature on physical activity and obesity and television viewing and obesity is equivocal (Malina et al., 2004; Marshall, Biddle, Gorely, Cameron, Murdey, 2004; Shah \& Jeffery, 1991; Manos et al., 1993; Treuth et al., 1998). Although television viewing and video games are highly visible forms of physical inactivity, the results highlight the need to examine other forms of physical inactivity in the daily lives of children and adolescents - school, study, reading, music, art and the like, and of course motorized transport (Malina, 2008).

\section{CONCLUSION}

In summary, evidence suggests that a record of seven days provides a reliable estimate of the usual pattern of physical activity in youth (Trost et al., 2000). About one-half of urban Mexican boys 9 to 13 years had an adequate level of physical activity over the preceding seven days (PAQ score $\geq 3.0$ ). However, the majority of boys $14-18$ years and girls in the three age groups had relatively little moderate-to-vigorous physical activity in the past week. Boys and girls in the two younger age groups spent, on average, about 5 and 4 hours per day, respectively, in screen activities in contrast to about 4 and 3 hours per day, respectively, in older boys and girls. Thus, the majority of urban Mexican youth in this sample had insufficient physical activity and seemingly too much inactivity, both of which have negative implications on health status. 


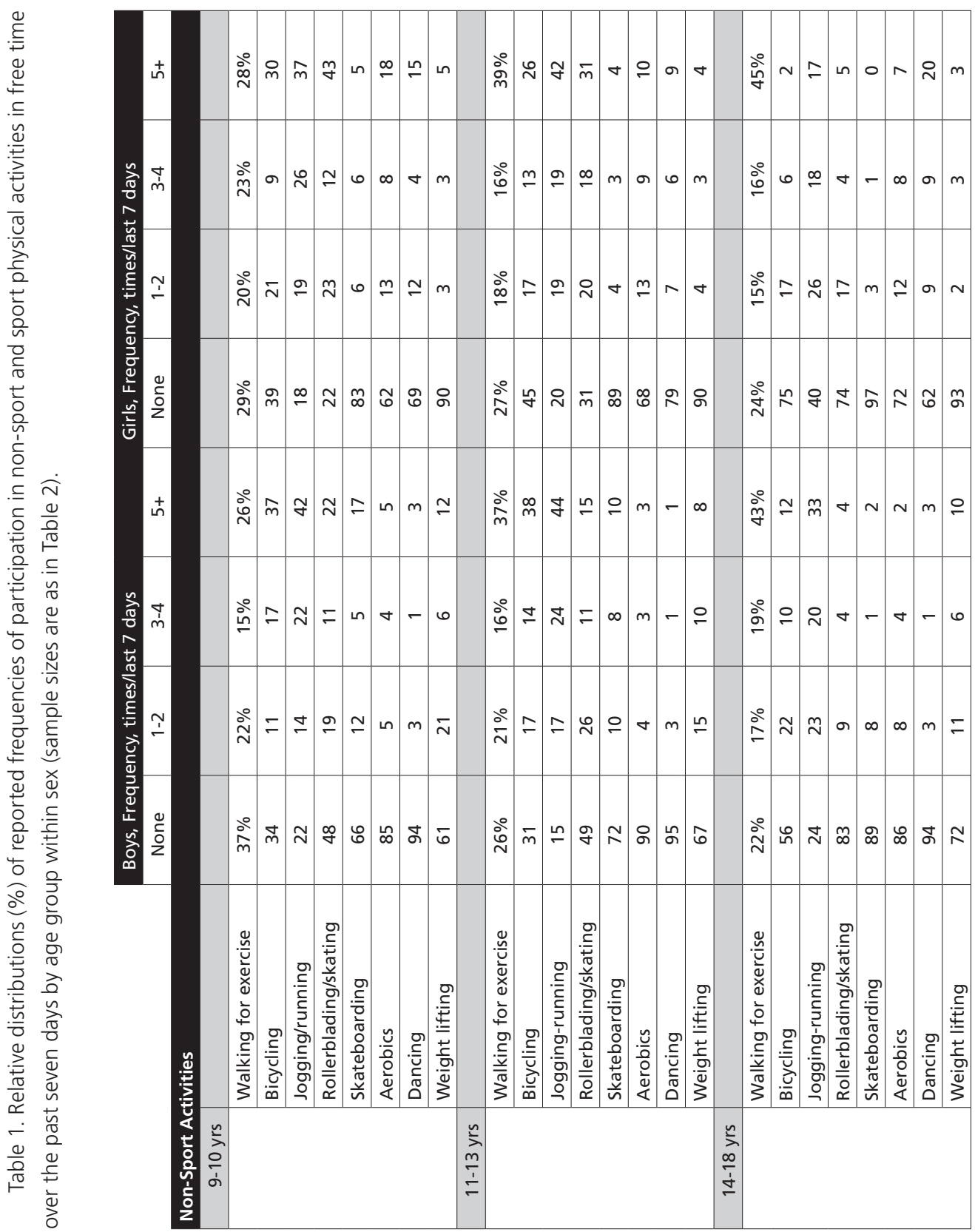




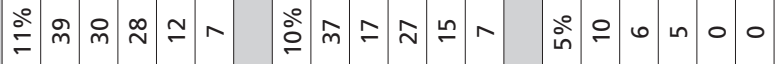

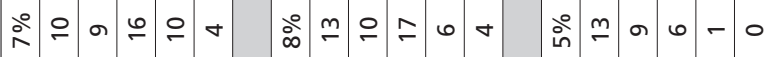

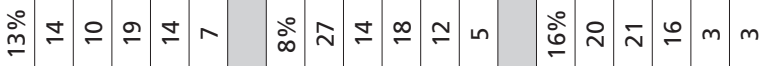

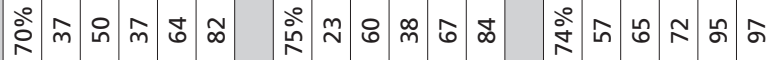

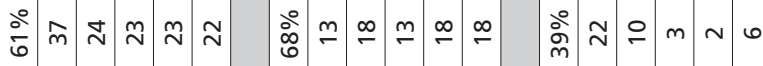

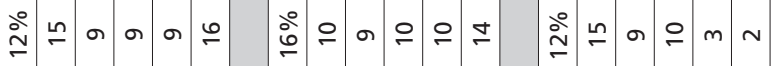

ळे

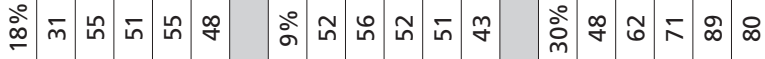

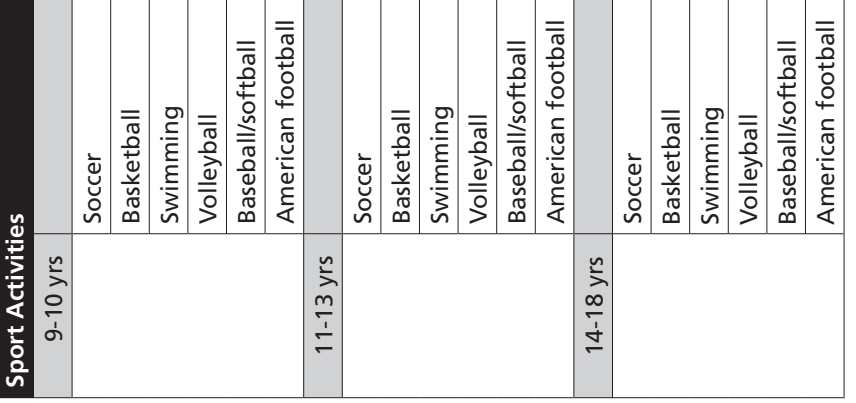




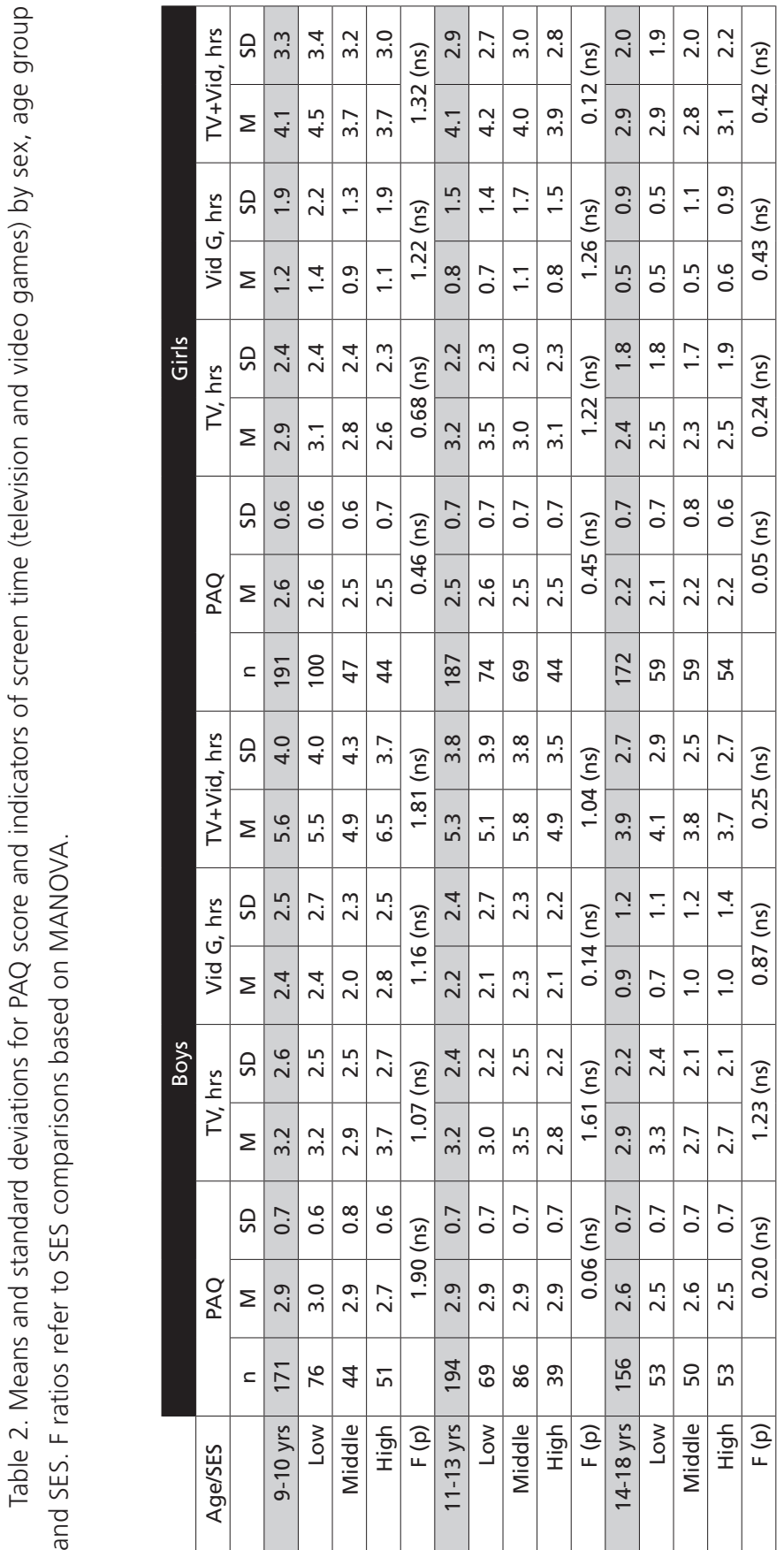


Table 3. Sex differences in physical activity and screen time within age group: means, standard deviations and results of MANOVAs.

\begin{tabular}{|c|c|c|c|c|c|c|c|c|}
\hline \multirow{2}{*}{ Age, yrs } & \multirow[b]{2}{*}{ Variable } & \multicolumn{2}{|c|}{ Boys } & \multicolumn{2}{|c|}{ Girls } & \multirow[b]{2}{*}{$\mathrm{F}$} & \multirow[b]{2}{*}{$P$} & \multirow[b]{3}{*}{$M>F$} \\
\hline & & M & SD & $M$ & SD & & & \\
\hline \multirow[t]{4}{*}{$9-10$} & PAQ score & 2.9 & 0.7 & 2.6 & 0.6 & 16.33 & $<0.000$ & \\
\hline & TV, hrs & 3.2 & 2.6 & 2.9 & 2.4 & 1.90 & ns & \\
\hline & Video Games, hrs & 2.4 & 2.5 & 1.2 & 1.9 & 25.49 & $<0.000$ & $M>F$ \\
\hline & TV + Video, hrs & 5.6 & 4.0 & 4.1 & 3.3 & 16.29 & $<0.000$ & $M>F$ \\
\hline \multirow[t]{4}{*}{$11-13$} & PAQ score & 2.9 & 0.7 & 2.5 & 0.7 & 34.05 & $<0.000$ & $M>F$ \\
\hline & TV, hrs & 3.2 & 2.4 & 3.2 & 2.2 & 0.89 & ns & \\
\hline & Videos Games, hrs & 2.2 & 2.4 & 0.8 & 1.5 & 42.26 & $<0.000$ & $M>F$ \\
\hline & TV + Video, hrs & 5.3 & 3.8 & 4.1 & 2.9 & 13.38 & $<0.000$ & $M>F$ \\
\hline \multirow[t]{4}{*}{$14-18$} & PAQ score & 2.6 & 0.7 & 2.2 & 0.7 & 28.16 & $<0.000$ & $M>F$ \\
\hline & TV, hrs & 2.9 & 2.2 & 2.4 & 1.8 & 4.98 & $<0.05$ & $M>F$ \\
\hline & Videos Games, hrs & 0.9 & 1.2 & 0.5 & 0.9 & 13.16 & $<0.000$ & $M>F$ \\
\hline & TV + Video, hrs & 3.9 & 2.7 & 2.9 & 2.0 & 12.38 & $<0.000$ & $M>F$ \\
\hline
\end{tabular}

Table 4. Age group differences in physical activity and screen time within sex: means, standard deviations and results of MANOVAs.

\begin{tabular}{|c|c|c|c|c|c|c|c|c|c|c|}
\hline & \multirow[b]{3}{*}{ Variable } & \multicolumn{6}{|c|}{ Age Groups, yrs } & & & \\
\hline & & \multicolumn{2}{|c|}{$9-10$} & \multicolumn{2}{|c|}{$11-13$} & \multicolumn{2}{|c|}{$14-18$} & \multirow[b]{2}{*}{$\mathrm{F}$} & \multirow[b]{2}{*}{$\mathrm{p}$} & \multirow[b]{2}{*}{ Comparisons } \\
\hline & & $M$ & SD & $\mathrm{M}$ & SD & M & SD & & & \\
\hline \multirow[t]{4}{*}{ Boys } & PAQ score & 2.9 & 0.7 & 2.9 & 0.7 & 2.6 & 0.7 & 11.58 & $<0.000$ & $9-10=11-13>14-18$ \\
\hline & TV, hrs & 3.2 & 2.6 & 3.2 & 2.4 & 2.9 & 2.2 & 0.68 & ns & \\
\hline & $\begin{array}{l}\text { Videos Games, } \\
\text { hrs }\end{array}$ & 2.4 & 2.5 & 2.2 & 2.4 & 0.9 & 1.2 & 21.62 & $<0.000$ & $9-10=11-13>14-18$ \\
\hline & TV + Video, hrs & 5.6 & 4.0 & 5.3 & 3.8 & 3.9 & 2.7 & 11.46 & $<0.000$ & $9-10=11-13>14-18$ \\
\hline \multirow[t]{4}{*}{ Girls } & PAQ score & 2.6 & 0.6 & 2.5 & 0.7 & 2.2 & 0.7 & 19.59 & $<0.000$ & $9-10=11-13>14-18$ \\
\hline & $\mathrm{TV}$, hrs & 2.9 & 2.4 & 3.2 & 2.2 & 2.4 & 1.8 & 6.00 & $<0.01$ & $9-10=11-13>14-18$ \\
\hline & $\begin{array}{l}\text { Videos Games, } \\
\text { hrs }\end{array}$ & 1.2 & 1.9 & 0.8 & 1.5 & 0.5 & 0.9 & 9.90 & $<0.000$ & $9-10>11-13=14-18$ \\
\hline & TV + Video, hrs & 4.1 & 3.3 & 4.1 & 2.9 & 2.9 & 2.0 & 9.69 & $<0.000$ & $9-10=11-13>14-18$ \\
\hline
\end{tabular}


Table 5. Age-adjusted means and standard errors for PAQ scores among boys and girls by categories of perceived physical activity and physical condition compared to peers of the same age and sex, and results of MANCOVAs with age as the covariate.

\begin{tabular}{|c|c|c|c|c|c|c|}
\hline & \multicolumn{3}{|c|}{ Boys } & \multicolumn{3}{|c|}{ Girls } \\
\hline & $\mathrm{n}$ & $M$ & SE & $n$ & $M$ & SE \\
\hline \multicolumn{7}{|l|}{$\begin{array}{l}\text { Perceived physical activity... } \\
\text { compared to others: }\end{array}$} \\
\hline$\ldots$ very inactive & 52 & 2.65 & 0.09 & 52 & 2.11 & 0.09 \\
\hline$\ldots$ less active & 79 & 2.57 & 0.08 & 110 & 2.08 & 0.06 \\
\hline$\ldots$ just as active & 232 & 2.74 & 0.04 & 243 & 2.45 & 0.04 \\
\hline ... little more active & 101 & 2.94 & 0.07 & 102 & 2.73 & 0.06 \\
\hline ... much more active & 57 & 3.24 & 0.09 & 40 & 2.94 & 0.10 \\
\hline$F(p)$ & \multicolumn{3}{|c|}{$10.71(<0.001)$} & \multicolumn{3}{|c|}{$25.16(<0.001)$} \\
\hline \multicolumn{7}{|l|}{$\begin{array}{l}\text { Perceived physical condition ... } \\
\text { compared to others: }\end{array}$} \\
\hline ... worse & 27 & 2.51 & 0.13 & 30 & 2.39 & 0.12 \\
\hline$\ldots$ less fit & 190 & 2.61 & 0.05 & 275 & 2.33 & 0.04 \\
\hline$\ldots$ very fit & 301 & 2.94 & 0.04 & 239 & 2.54 & 0.04 \\
\hline$F(p)$ & \multicolumn{3}{|c|}{$16.78(<0.001)$} & \multicolumn{3}{|c|}{$6.47(<0.01)$} \\
\hline
\end{tabular}

Table 6. Correlations between BMI and PAQ score and indicators of screen time (television and video games) and the by sex and age group.

\begin{tabular}{|c|c|c|c|c|c|c|c|c|}
\hline \multicolumn{1}{|c|}{} & \multicolumn{4}{c|}{ Boys } & \multicolumn{5}{c|}{ Girls } \\
\cline { 2 - 9 } & BMI/PAQ & BMI/TV & $\begin{array}{c}\text { BMI/ } \\
\text { Vid G }\end{array}$ & $\begin{array}{c}\text { BMI/ } \\
\text { TV+Vid }\end{array}$ & BMI/PAQ & BMI/TV & $\begin{array}{c}\text { BMI/ } \\
\text { Vid G }\end{array}$ & $\begin{array}{c}\text { BMI/ } \\
\text { V+Vid }\end{array}$ \\
\hline $9-10$ & 0.07 & -0.03 & -0.02 & -0.03 & 0.01 & $\begin{array}{c}0.14 \\
(p=0.06)\end{array}$ & -0.06 & 0.07 \\
\hline $11-13$ & $\begin{array}{c}-0.19 \\
(p<0.01)\end{array}$ & 0.01 & 0.01 & 0.01 & 0.00 & $\begin{array}{c}0.17 \\
(p<0.05)\end{array}$ & -0.04 & 0.11 \\
\hline $14-18$ & 0.04 & $\begin{array}{c}-0.15 \\
(p=0.06)\end{array}$ & 0.09 & -0.09 & -0.09 & 0.05 & 0.04 & 0.06 \\
\hline Total & -0.06 & -0.04 & 0.00 & -0.03 & -0.02 & $\begin{array}{c}0.14 \\
(p<0.01)\end{array}$ & -0.04 & $\begin{array}{c}0.09 \\
(p<0.05)\end{array}$ \\
\hline
\end{tabular}

a partial correlations, controlling for age 


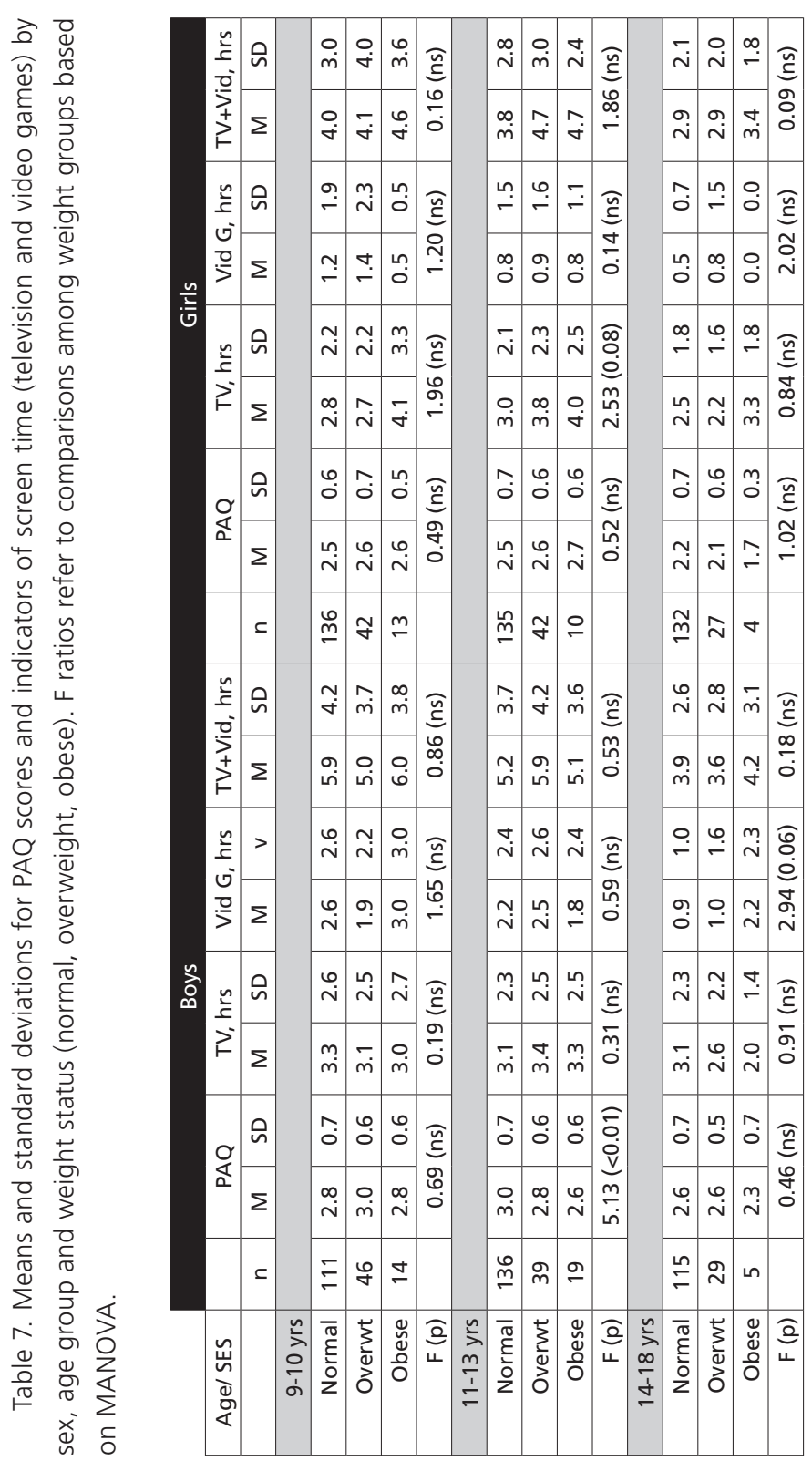


Table 8. Comparative data for PAQ scores in several samples of youth.

\begin{tabular}{|c|c|c|c|c|c|c|c|c|c|c|}
\hline & & \multicolumn{3}{|c|}{ Boys } & \multicolumn{3}{|c|}{ Girls } & \multicolumn{3}{|c|}{ Sexes Combined } \\
\hline Samples & Age, yrs & $\mathrm{n}$ & $\mathrm{M}$ & SD & $\mathrm{n}$ & $\mathrm{M}$ & SD & $n$ & M SD & SD \\
\hline This study, Mexico, urban & $9-10$ & 175 & 2.8 & 0.7 & 196 & 2.6 & 0.6 & & & \\
\hline This study, Mexico, urban & $11-13$ & 194 & 2.9 & 0.7 & 190 & 2.5 & 0.7 & & & \\
\hline European Americans ${ }^{a}$ & $8.7 \pm 0.5$ & & & & & & & 146 & 3.4 & 0.8 \\
\hline African Americans a & $8.7 \pm 0.6$ & & & & & & & 268 & 3.4 & 0.7 \\
\hline \multirow[t]{2}{*}{ Canada, urban ${ }^{\text {b }}$} & $8-13$ & & & & & & & 89 & 3.2 & 0.8 \\
\hline & $9-14$ & & & & & & & 97 & 3.3 & 0.7 \\
\hline Canada, urban ${ }^{c}$ & $8-13$ & 52 & 3.1 & 0.6 & 58 & 2.9 & 0.7 & & & \\
\hline rural & $8-13$ & 75 & 3.1 & 0.7 & 90 & 2.9 & 0.7 & & & \\
\hline rural Mennonite & $8-13$ & 67 & 3.0 & 0.6 & 57 & 3.1 & 0.6 & & & \\
\hline Canada, urban ${ }^{d}$ & $9-15$ & 125 & 3.4 & 0.7 & 90 & 3.0 & 0.7 & & & \\
\hline This study, Mexico, urban & 14-18 & 156 & 2.6 & 0.7 & 174 & 2.2 & 0.7 & & & \\
\hline Brazil, urban ${ }^{\mathrm{e}}$ & 14-15 & 125 & 2.3 & 0.6 & 202 & 2.0 & 0.6 & & & \\
\hline Canada, urban ${ }^{f}$ & $13-20$ & 41 & 2.5 & 0.7 & 4 & & & & & \\
\hline
\end{tabular}

aMoore et al., 2007

'Kowalski, Crocker, \& Faulkner, 1997

'Tremblay et al., 2003

${ }^{d}$ Crocker, Bailey, Faulkner, Kowalski, \& McGrath, 1997

e Rosendo da Silva \& Malina, 2000

${ }^{\dagger}$ Kowalski, Crocker, \& Kowalski, 1997

\section{ACKNOWLEDGMENTS}

This research was supported in part by a grant from the International Education Program at Michigan State University. The support and encouragement of Dr. Jack Schwille of the International Education Program is gratefully acknowledged and appreciated. The assistance and patience of the school authorities, and of course, the students are also gratefully acknowledged and appreciated. Finally, the assistance of colleagues at ENAH, Denise Lambaer Urrutia, Martha Hurtado Santoyo, Aída Pérez Cárdenas, Hugo Torres López, Marcela del Olmo Ruiz and Arturo Gómez Serrano, is recognized and gratefully appreciated. 


\section{REFERENCES}

Ainsworth, B. E., Haskell, W. L., Whitt, M. C., Irwin, M.L., Swartz, A.M., Strath, S.J., Leon, A. S. (2000). Compendium of physical activities: An update of activity codes and MET intensities. Medicine and Science in Sports and Exercise, 32, S498-S516.

Bandini, L. G., Schoeller, D. A., \& Dietz, W. H. (1990). Energy expenditure in obese and nonobese adolescents. Pediatric Research, 27, 198-203.

Boracino, A., Lemma, P., lannotti, R. J., Zambon, A., Dalmasso, P., Lazzeri, G., Caavallo, F. (2009). Socioeconomic effects on meeting physical activity guidelines: Comparisons among 32 countries. Medicine and Science in Sports and Exercise, 41, 749-756.

Centers for Disease Control and Prevention. (2005). GSHS: Global School-Based Student Health Survey. AtIanta, GA: Centers for Disease Control and Prevention. Retrieved 26 June 2005 from http://www.cdc. gov/gshs/index.htm.

Cole,T. J., Bellizzi, M. C., Flegal, K. M., \& Dietz, W. H. (2000). Establishing a standard definition for child overweight and obesity worldwide: International survey. British Medical Journal,320, 1240-1243.

Cole, T. J., Flegal, K. M., Nicholls, D., \& Jackson, A.A. (2007). Body mass index cut offs to define thinness in children and adolescents: International survey. British Medical Journal, 335, 194-201.

Crocker, P. R. E., Bailey, D. A., Faulkner, R. A., Kowalski, K., C, \& McGrath, R. (1997). Measuring general levels of physical activity: Preliminary evidence for the Physical Activity Questionnaire for Older Children. Medicine and Science in Sports and Exercise, 29, 1344-1349.

Crocker, P. R. E., Holowachuk, D. R., \& Kowalski, K. C. (2001). Feasibility of using the Tritrac motion sensor over a 7-day trial with older children. Pediatric Exercise Science, 13, 70-81.

Currie, C., Roberts, C., Morgan, A., Smith, R., Settertobulte, W., Samdal, O., \& Rasmussen, V. B. (Eds.). (2004). Young People's Health in Context: International report from the HBSC 2001/02 survey. WHO Policy Series: Health policy for children and adolescents, Issue 4. Copenhagen: WHO Regional Office for Europe.

Godin, G., \& Shephard, R. J. (1985). A simple method to assess exercise behavior in the community. Canadian Journal of Applied Sport Science, 10, 141-146.

Hernández. B., Gortmaker, S. L., Colditz, G. A., Peterson, K. E., Laird, N. M., \& Parra-Cabrera, S. (1999). Association of obesity with physical activity, television programs and other forms of video viewing among children in Mexico City. International Journal of Obesity, 23, 845-854.

Hernández, B., Gortmaker, S. L., Laird, N. M., Colditz, G. A., Parra-Cabrera, S., \& Peterson, K. E. (2000). Validez y reproducibilidad de un cuestionario de actividad e inactividad fisica para escolares de la ciudad de México. Salud Pública de México, 42, 315-23.

Hernández, M. I., Villabos, A., \& Rauda, J. (2006). Actividad fisica en adolescentes. In G. Olaiz, J. Rivera, T. Shamah, R. Rojas, S. Villalpando, M. Hernández, J. Sepulveda. (Eds.), Encuesta Nacional de Salud y Nutrition (pp. 105-109). Cuernavaca, México: Instituto Nacional de Salud Publica.

Hoehner, C. M., Soares, J., Parra Perez, D., Ribeiro, I. C., Joshu, C.E., Pratt, M.,...Brownson, R. C. (2008). Physical activity interventions in Latin America: A systematic review. American Journal of Preventive Medicine, 34, 224-233. 
Jantz, K. F., Lutuchy, E. M., Wenthe, P., \& Levy, S. M. (2008). Measuring activity in children and adolescents using self report: PAQ-C and PAQ-A. Medicine and Science in Sports and Exercise, 40, 767-772.

Kowalski, K. C., Crocker, P. R. E., \& Faulkner, R. A. (1997). Validation of the Physical Activity Questionnaire for Older Children. Pediatric Exercise Science, 9, 174-186.

Kowalski, K. C., Crocker, P. R. E., \& Kowalski, N. P. (1997). Convergent validity of the Physical Activity Questionnaire for Adolescents. Pediatric Exercise Science, 9, 342-352.

Lazcano-Ponce, E. C., Hernández, B., Cruz-Valdez, A., Allen, B., Diaz, R., Hernández, C., Hernández-Avila, M. (2003). Chronic disease risk factors among healthy adolescents attending public schools in the State of Morelos, Mexico. Archives of Medical Research, 34, 222-236.

Malina, R. M. (1990). Growth, exercise, fitness, and later outcomes. In C. Bouchard, R. J. Shephard, T. Stephens, J. R. Sutton, \& B. D. McPherson (Eds.), Exercise, Fitness, and Health: A Consensus of Current Knowledge (pp. 637-653). Champaign, IL: Human Kinetics.

Malina, R. M. (2008). Biocultural factors in developing physical activity levels. In A. L. Smith \& S. J. H. Biddle (Eds.), Youth Physical Activity and Inactivity: Challenges and Solutions (pp. 141-166). Champaign, IL: Human Kinetics.

Malina, R. M., \& Bouchard, C., Bar-Or, O. (2004). Growth, Maturation, and Physical Activity (2 ${ }^{\text {nd }}$ ed.). Champaign, IL: Human Kinetics.

Marshall, S. J., Biddle, S. J. H., Gorely, T., Cameron, N., \& Murdey, I. (2004). Relationships between media use, body fatness and physical activity in children and youth: a meta-analysis. International Journal of Obesity, 28, 1238-1246.

Manos, T. M., Gutin, B., Rhodes, T., Spandorfer, P. R., Jackson, L. W., \& Litaker, M. S. (1993). Energy expenditure and intake in obese and nonobese African American girls. Annals of the New York Academy of Sciences, 699, 275-277.

Moore, J. B., Hanes, J. C., Barbeau, P., Butin, B., Treviño, R. P., \& Yin, Z. (2007). Validation of the physical activity Questionnaire for older children in children of different races. Pediatric Exercise Science, 19, 6-19.

Physical Activity Guidelines Committee. (2008). Physical Activity Guidelines Committee Report, Part G. Section 9. Youth. Washington, DC: Department of Health and Human Services, pp. G9-1-G9-33.

Perez, A., Reininger, B. M., Aguirre Flores, M. I., Sanderson, M., \& Roberts, R. E. (2004). Physical activity and overweight among adolescents on the Texas-Mexico border. Revista Panamericana de Salúd Publica, 19, 244-51.

Rivera Dommarco, J., Cuevas Nasu, L., Shamah Levy, T., Villalpando Hernández, S., Avila Arcos, M. A., \& Jimenez Aguilar, A. (2006). Estado nutricio. In G. Olaiz, J. Rivera, T. Shamah, R. Rojas, S. Villalpando, M. Hernández, J. Sepulveda. (Eds.), Encuesta Nacional de Salud y Nutrition (pp. 85-103). Cuernavaca, México: Instituto Nacional de Salud Pública.

Rosendo da Silva, R. C., \& Malina, R. M. (2000). Nivel de atividade fisica em adolescentes do Municipio de Niterói, Rio de Janeiro, Brasil. Cadernos de Saude Publica, 16, 1091-1097.

Rosendo da Silva, R. C., \& Malina, R. M. (2003). Sobrepeso, atividade física e tempo de televisão entre adolescentes de Niterói, Rio de Janeiro, Brasil. Revista Brasileira de Ciencia e Movimento, 11(4), 63-66, 12(3), 61 (tables). 
Sallis, J. F., Haskell, W. L., Wood, P.D., Fortmann, S.P., Rogers, T., Blair, S.N., \& Paffenbarger, R. S. J. (1985). Physical activity assessment methodology in the Five City Project. American Journal of Epidemiology, 121, 91-106.

Shah, M., \& Jeffery, R. W. (1991). Is obesity due to overeating and inactivity, or to a defective metabolic rate? A review. Annals of Behavioral Medicine, 13, 73-81.

Strong, W. B., Malina, R. M., Blimkie, C. J. R., Daniels, S. R., Dishman, R. K., Gutin, B.,...Trudeau, F. (2005). Evidence based physical activity for school youth. Journal of Pediatrics, 146, 732-737.

Tremblay, M. S., Barnes, J. D., Copeland, J. L., \& Esliger, D. W. (2003). Conquering childhood inactivity: Is the answer in the past? Medicine and Science in Sports and Exercise, 37, 1187-94.

Treuth, M. S., Figueroa-Colon, R., Hunter, G. R., Weinsier, R. L., Butte, N. F., \& Goran, M, I. (1998). Energy expenditure and physical fitness in overweight vs non-overweight prepubertal girls. International Journal of Obesity Research, 22, 440-447.

Trost, S. G., Pate, R.R., Freedson, P. S., Sallis, J. F., \& Taylor, W. C. (2000). Using objective physical activity measures with youth: How many days of monitoring are needed? Medicine and Science in Sports and Exercise, 32, 426-431.

Youth Risk Behavior Survey. (2004). National Youth Risk Behavior Survey: 1991-2003. Trends in the prevalence of physical activity. Atlanta, GA: Department of Health and Human Services, Centers for Disease Control and Prevention. Retrieved 26 May 2004 from http://ww.cdc.gov/yrbss. 
Página deixada propositadamente em branco 